\title{
Competencies in Software Engineering of InformaticsGraduates at Coordinator of Higher Education Region(Kopertis III) Based on Final Assignment Evaluation
}

\author{
Kursehi Falgenti $^{\text {a) }}$ and Danang Sutrisno ${ }^{\text {b) }}$ \\ University of Indraprasta PGRI, Jl. Raya Tengah Kelurahan Gedong, Pasar Rebo,Jakarta Timur, Indonesia.

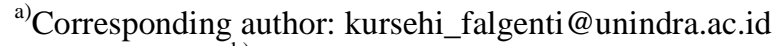 \\ b)dngs3674@gmail.com
}

\begin{abstract}
The aim of this research is to analyze texts of undergraduate thesis by graduate students of Technical Informatics in regards to know the duration of study, technical skills in software engineering, complexities of application. 200 samples of final assignments as research subjects were evaluated taken from 10 private university libraries at Coordinator of Private Universities (Kopertis) Level Region III. The topic of final assignment analyzed is about applicaton software design. Sample analysis of this research uses open coding method. The first phase of open coding aims at knowing the duration of study and developing topical categories of undergraduate thesis. The second step of open coding is to classify technical skills in process of software engineering; the classification itself is based on Life Cycle Skill Areas in Software Engineering Competency Model (SWECOM) designed by IEEE Computer Society. The third step is to look at complexities of the application. Further, selective coding is done to determine the competency software engineering of undergraduate students at Coordinator of Private Universities Level Region III. Competencies in software engineering can be known through analyzing the duration of the study, technical skills and complexity of application. Result of this study has shown that many graduates of Technical Informatics Program do not complete their study on time; the duration they accomplish their study is beyond than 7-8 semesters. In software engineering, the graduates have good skills in designing process, however the skills to analyze and skills to application testing need more improvement. The applications produced by undergraduate students have low and medium complexities. A small number of applications which have high level of complexities. Based on this research, to improve students' competency in software engineering need to do some improvements: 1) to put big effort of students in software engineering, 2) to improve technical skills of students in the stages of System Development Life Cycle (SDLC). The result of this research can be used as basic information for Study Program of Technical Infromatics of private universities, more specificly at Coordinator of Private Higher Education (Kopertis) Level Region III to develop curiculum in the field of software engineering based National Qualification Framework (KKNI) and National Standards for Higher Education (SNDIKTI).
\end{abstract}

Keywords: Competency, Software Engineering, final assignment, SWECOM, open coding

\section{INTRODUCTION}

The undergraduate thesis as final assignment has to be written in form of a research writing. For undergraduate students, this undergraduate thesis is usually called skripsi. Nearly all of universities in Indonesia utilize undergraduate thesis is one of requirements to complete undergraduate degree. Thesis topics taken by students have to be relavant with their areas of study. For students of technical informatics, application sofware design is one of the frequent topics choosen by students. Students who pick up this topic are required to design and develop an application to overcome a particular problem utilizing certain tools and available methods. Planning steps, analysis steps, design steps and testing sofware steps are clearly described in the thesis. Students require to defense their research result in front of thesis examination committee members determined by university. The students declared pass through this examination are entitled an undergraduate degree and have owned qualification and competency in the field of informatics engineering. An qualified research is a research that produces results which have valuable benefits for solving people's problems and also this research comprises creative and innovative aspects. Thus, logically, a well written undergraduate thesis come from students who have competency in designing software applications. 
Most of private universities in Special Capital Region (DKI) of Jakarta and surrounding areas Jakarta have offered program study of technical informatics. Universities in Jakarta and surrounding areas Jakarta are under coordination of Coordinator of Private Universities (Kopertis) Level Region III. Those universities have graduated a lot of undergraduates degree students in technical informatics. Many of whom have choosen research topic in the areas of application software design. Along with the increasing number of technical informatics students, automatically the quantity of undergraduate thesis written by students also goes up. From the undergraduate thesis, it can be explained the information on how long students spend to complete their study. Further, it can be obtained information on what application created by students and how the process of creating the software.

Through answering the research questions above it can be known technical skills in software engineer of students who have completed technical informatics at Coordinator of Private Universities (Kopertis) Level Region III. Technical skills have important role to understand the competencies in the field software engineer based on Software Engineering Compentency Model (SWECOM) created by Computer Society IEEE (2014). Competencies of undergraduate students in software engineering can be seen through the text of their undergraduate thesis. of Text of undergraduate thesis is instrument In general, textual analysis of undergraduate thesis can be essential to know software engineering competencies in three components: a) the duration of study and characteristics of application developed as final assignment, b) process to develop application started from analysis, planning, developing and testing step, c) complexity of application.

\section{LITERATURE STUDY}

It is widely known that information technology (IT) disciplines in educational context is distinguished from other fields. One of the noticiable differences is that teaching IT is mostly related to practical skills. Like in software engineering, computer programming is part of curriculum in many universities in Indonesia. Learning computer programming languages cannot be taught through theoritical approach, it takes many practical tasks to develop technical expertise on programming concept and also using algorithms concept in mapping real problems into structure of programming languages (Grossdan Pinkwart,2015). Some research on that issue have been conducted, Ihantola et al., (2010) and Jenkins et al., (210) show that many students find difficulties in learning basic concepts of programming. Apiola and Tedre (2012) state that learning programming for students of developing countries has poor ability in mastering programming languages. Therefore, the impact is that they do not have sufficient understanding about complex computer programming.In examination, students usually cheat in doing their examination and plagiarism in completing final assignments is something common to do .

\section{Study Program of Software Engineering}

Many universities offer program study of software engineering to improve their reputation. This view is considered as a myth and baseless (Saedian et. all, 2002). Having program study of software engineering can improve the image, however, it is important to figure out the financial aspects spent in the long term cost; a huge amount of budget is required to build and operate computer laboratory.

APTIKOM (2015) has mapped out the competencies of undergraduate students through catagorizing into five different categories of computing disciplines, they are computer engineering, computer science (informatics/CS), software engineering (SE), information system, dan information technology (IT). DIKTI also has standarized nomenclature study program under computer science group as follows: (1) computer system(Sistem Komputer), (2) Computer Science/Informatics(Ilmu Komputer/Informatika, (3) Information system (Sistem Informasi), (4) Information Technology (Teknologi Informasi), and (5) Software Engineering (Rekayasa Perangkat Lunak). InformationTechnology and Software engineering are relatively new diciplines. Sofware Engineering is developed from Technical Informatics while Information Technology is established from the development of Management Informatics. The name of software engineering study (Studi Rekayasa Perangkat Lunak) has not been commonly used at Computer Science for undergraduate level in Indonesia. In fact, there has not been many universities that open those both majors for undergraduate level. Sofware Engineering Program is still under the domain of Technical Informatics while Information Technology is under Management Informatics. 
There are 58 Study Programs of Technical Informatics atCoordinator of Private Universities Region Level III. 30 of the study programs have lecturer ratio which is 1:30. 12 of the universities have the population of Technical Informatics students below or equal to 100 students. 6 universities have the population of Technical Informatics students beyond than 1000 students. While data from BAN-PT there are 53 private universities which have been acredited at Coordinator of Private Universities (Kopertis) Region Level III. From 53 universities, there are four study programs of Technical Informatis which have been acredited A, 15 of Study Program of Technical Informatics which are acredited B and the rest 34 of study program are got C. There four study programs which have not been acredited.

\section{Final Assignment/ Undergraduate Thesis/Skripsi}

Completing final assignment which is called undergraduate thesis is evidence of students' academic performance; the final assignment is supposed to be relevant to the field of study taken by students. In Indonesian context, underdraduate thesis is usually called with skripsi. Writing undergraduate thesis and presenting it in front of committee members is a requirement to complete undergraduate decree (Wirartha, 2006). The text of the undergraduate thesis written by students is kind of knowledge extraction after students take the course for almost four years. The graduate thesis should be presented in front of the undergraduate thesis committee and students should be able to defend their argumentation. The minimum grade to be declared a pass on computer science is $\mathrm{C}$. Presenting undergraduate thesis is final assessment for students before they complete their study.

\section{Learning Evaluation}

The major focus of evaluation is to provide information that can be use as consideration to take a decision (Widoyoko 2009). Evaluation process is extremelly essential in learning and teaching process. The process of evaluation or assessment started from daily learning activities in the class until final examination at the end of one semester. This evaluation determine the pass or fail of students on certain course. At the end of academic year universities perform final evaluation to decide students who can be declared a pass and entitled a bachelor's degree. The final evaluation at the end of academic year is through presenting students' undergraduate thesis, however, there are some universities do not require their students to write undergraduate thesis, instead they asked their students to design certain task.

For study program of technical informatics, students are required to choose topic about application software design. In their undergraduate thesis, students have to create particular application to solve a problem in the certain circumtance. In developing their application, students have to use certain tool and method. Following are general information need to be understood in choosing topics in the areas of software engineering:

1. Software platform

Software platforms vary; there are desktop platform for single user. There is a web platform that can serve multiple users. The web platform is run through a web server which processes ordering from clients. Information resulting from the processing step displayed in certain browser. A web-based application can be run as script by processor like ASP or PHP. Script and program will give information in HTML format to webserver and then passed through browser and also to process infromation from web server, for example saving data to data base. Beside webbased platform,presently mobile platform is growing very fast. The growing of celular technology has produced smartphone. In smartphone, many applications can be run on the mobile device to enhance productivity or to provide many choices entertainment applications. Cloud platform run oncloud computing. Cloud platform provides services. The existence of cloud platformhas changed the paradigm of application program; previously an application program is a traded product, today the program application running on platform cloud can be rent virtually.

2. SoftwareDomain

Software created to a wide range of domains from business application like accounting application, inventory application. Educational applications like information system in enrolling new students, information system for academic purposes. Game applications for educational perposes or entertainment applications.

3. Software Architecture

Initially, software architecture is a stand alone application. The application created for one single user. The growing of networking technology has made architecture appliation keep abreast of new hardware development. 
Through the support of programming languages for distributed system client-server architecture can be developed. The fast growing of the Internet technology enables application developed on internet base. Service Oriented Architecture (SOA) is an architecture standard to develop service-based application run on web service.

\section{COMPETENCIES}

Learning evaluation or assessment on the basis of competencies has long been used. In 1970s, the concept of mastery learning and comptency-based teacher education were known. In mastery learning, a student declared a pass if he master $8 \%$ of learning materials (Yusuf, 2015). Yusuf (2015) defines comptencies as integrated skills, manners and knowledge including basic values that should be demonstrated or reflected in daily habit and the ability to think critically. APTIKOM defines competency as accumulated performance of students in doing a number of task description. The task description have certain measurable and structural parameters consisting of independence aspect and perform individual responsibility.

\section{Competencies in Software Engineering}

The term programming emerged in 1960s as a job to make computer codes. Along with the growing of computer science, the term programming then has been developed into sofware engineering. Definition of software engineering is getting broader, it is not limited creating programming codes on the computer, but it is a part of computer science with systematic approach in building and maintain the sofware (Wirth, 2008).

Software Engineering Competency Model (SWECOM) is aproject of IEEE Computer society. SWECOM Ver.1 consists of five components (figure 1). From five components of SWECOM, technical skills is the most important component. Technical skills are divided into two group which are software engineering life cycle skill area and crosscutting skill area. Software engineering life cycle skill area cover skills required to overcome some working activities within stages of developing software. In each of software development step, there are a number of skills that is supposed to be mastered (Table 1).

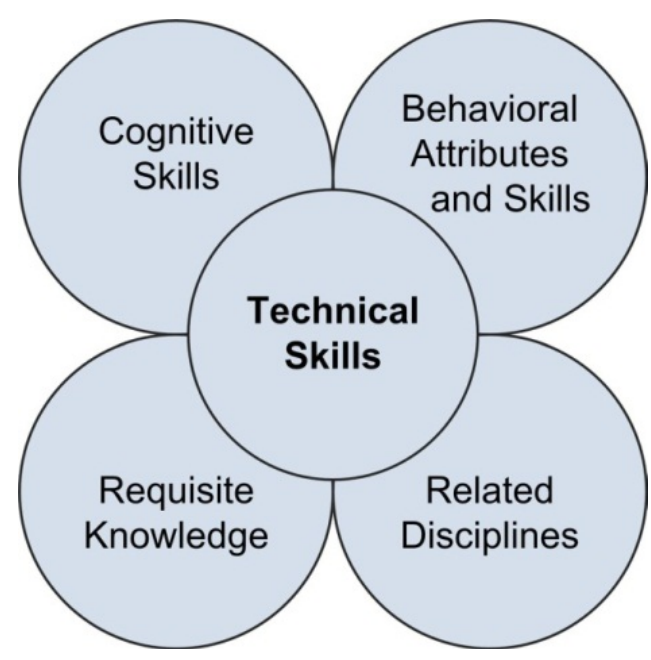

FIGURE 1. SWECOM Components ( SWECOM, 2014)

Skills in Software Engineeeing Life Cycle Skill Area is organized based stages of System Development Life Cycle (SDLC). Steps in SDLC consists of planning, analyzing, designing, developing, testing and taking care of the application. Not all of the SDLC stages can be analyzed through the text of undergraduate thesis. The final stage which is preserving software cannot be found in undergraduate thesis. 
TABLE 1. Software Engineering Life Cycle Skill Areas and Skills

\begin{tabular}{|c|c|}
\hline LifeCycleSkillAreas & Skills \\
\hline $\begin{array}{l}\text { Software Requirements Skills } \\
\text { References: } \\
\text { [ACM 2004] } \\
\text { [Laplante 2009] } \\
\text { [Robertson 2012] } \\
\text { [SWEBOK 2014] } \\
\text { [Wiegers 2013] }\end{array}$ & $\begin{array}{l}\text { Software Requirements Elicitation } \\
\text { Software Requirements Analysis } \\
\text { Software Requirements Specification } \\
\text { Software Requirements Verification and Validation } \\
\text { Software Requirements Process and Product } \\
\text { Management }\end{array}$ \\
\hline $\begin{array}{l}\text { Software Design Skills } \\
\text { References: } \\
\text { [IEEE 1016-2009] } \\
\text { [IEEE 12207-2008] } \\
\text { [IEEE 15528-2008] } \\
\text { [SWEBOK 2014] }\end{array}$ & $\begin{array}{l}\text { Software Design Fundamentals } \\
\text { Software Design Strategies and Methods } \\
\text { Software Architectural Design } \\
\text { Software Design Quality Analysis and } \\
\text { Evaluation }\end{array}$ \\
\hline $\begin{array}{l}\text { Software Construction Skills } \\
\text { References: } \\
\text { [ACM 2004] } \\
\text { [Fowler 1999] } \\
\text { [Hunt 1999] } \\
\text { [McConnell 2004] } \\
\text { [SWEBOK 2014] }\end{array}$ & $\begin{array}{l}\text { Software Construction Planning } \\
\text { Managing Software Construction } \\
\text { Detailed Design and Coding } \\
\text { Debugging and Testing } \\
\text { Integrating and Collaborating }\end{array}$ \\
\hline $\begin{array}{l}\text { Software Testing Skills } \\
\text { References: } \\
\text { [IEEE 730-2002] } \\
\text { [IEEE 829-2008] } \\
\text { [IEEE 1012-2012] } \\
\text { [Myers 2011] } \\
\text { [SWEBOK 2014] }\end{array}$ & $\begin{array}{l}\text { Software Test Planning } \\
\text { Software Testing Infrastructure } \\
\text { Software Testing Techniques } \\
\text { Software Testing Measurement and Defect Tracking }\end{array}$ \\
\hline $\begin{array}{l}\text { Software Sustainment Skills } \\
\text { References: } \\
\text { [IEEE 12207-2008] } \\
\text { [ISO/IEC/IEEE 24765:2010] } \\
\text { [IEEE 828-2012] } \\
\text { [Lapham 2006] } \\
\text { [SWEBOK 2014] }\end{array}$ & $\begin{array}{l}\text { Software Transition } \\
\text { Software Support } \\
\text { Software Maintenance }\end{array}$ \\
\hline
\end{tabular}

\section{Requirement Analysis}

Planning, analyzing and designing steps are initial process in developing software in SDLC. At the planning step is more into administratif job, deciding scope and human resources getting involved in developing project. Analysis phase is steps to understand business process, then it is integrated to application that will be created. Analysis to capture user needs is a crucial point in creating application. If need analysis does not cover user needs, it will consequently affect the next stages. If that situation happens, the development of software should go back to initial step until the user needs are fulfilled. Moreover, the effect will also cause additional cost and human resources cost. Skills needed in analysis step is skill to determine user needs of the software. In SWECOM, skills determine software needs. The skills required to fulfill software needs are to extract software needs, to analyze software needs, to determine specifications of software needs. Haroon (2012) explains that strategy advised in doing managerial 
process of need analysis is implementable techniques such as brainstorming of need extraction, discussing the project, negotiating the needs, having technical specification to document the needs, evaluating of need documentation to verify and validate the needs. It is also necessary to organize meeting for organizing the needs. In designing step, skills required based on SWECOM is basic knowledge of software engineering, method and software designing strategy, software designing architecture and skill in designing the quality control of the software.

\section{Planning}

Application is designed in designing step. Designing is prosess of modelling of requirements which have been extracted in the form of abstraction. Abstraction in the format of diagram started from general level until more specific level. The objectives of modelling is to make sure business process integrated to the software can be understood by programmer.

Procedural approach in designing uses data flow diagram, zero diagram and detailed diagram in modelling application design. The emerging of object oriented-programming paradigm, Unified Modelling Language (UML) has been a standard in application designing of oriented-object programming. Diagram used to design application using UML is use case diagram, activity diagram, sequence diagram, class diagram and so on. Service-oriented designing has been adopted along with the emerging of cloud computing technology which provides various types of cloud service started from application, paltform and infrastructure service.

In designing step, skills required based on SWECOM is basic knowledge of software engineering, method and software designing strategy, software designing architecture and skill in designing the quality control of the software.

\section{Development}

Software construction is the collection of activities and processes for converting design specifications into functional software solutions that meet customer needs. At this stage, programming codes created in regards to designing of prior steps. Strategy and tool used have an important role at this stage. The selected programming languages and designing method is connected to the application platform and application architecture. Programming languages like Basic and ADA are used in procedural developing. A number of programming languages such as Visual Basic and $\mathrm{CC}++$ can be used to program through procedural approach and object-oriented approach Blansit (2010). While creating programming code using Java is one hundred persen object-oriented approach.

Developing software using traditional approach generally adopts waterfall model. This model consists of six steps: planning, analyzing, designing, implementing, deployment and maintaining. Waterfall model in designing application conducted more structural process in which step by step must be followed rigidly. That is why many consider that this model is too rigid. New technique to organize more flexible in desiging software has been developed, for example prototyping method(Floyd 1984). Waterfall model is developed further with incremental way using "coding and editing" approach. This model is well-known with Spiral model (1988)

A lot of applications are widely used in the field of business and trade. The fast growing of Internet makes more flexible in the form of iteratif and incremental development. This concept was started by the emerge of Rapid Application Development (RAD) in 1990s. Agile concept and Agile Manifesto offers more revolusioner development (Schwaber 2004, Holcombe 2008).

\section{Testing}

Testing steps in undergraduate thesis examination only black boxtests to ensure all functions in the applicaton run well. Every input will display output without knowing the details. In undergraduate thesis examination, testing of the progam is part of the examination itself. This testing is usually adhoc performed by committe members of the undergraduate thesis examination. 


\section{Proceeding \\ International Seminar on \\ Mathematics, Science, and Computer Education}

Of five steps in SDLC, there are four steps that can utilized to know technical skills of graduate students of technical informatics. Technical skills can be identified through collecting information from four steps in SWECOM models.

\section{RESEARCH METHOD}

This research employs qualitative approach and open coding method. Open coding is used to analyze the text. Open coding is a process to break up the data into unit meanings (Moghaddam, 2006). It is called open coding since at the analysis step the data analyzed through open concept and not focus on specific issues. Coding process is an analysis of textual content through giving labelling concepts for chunk of data, defining and developing a number of categories based property and dimension of qualitative data.

200 of undergraduate thesis samples are taken from 10 university libraries under Coordinator of Higher Education (Kopertis) Region Level III. Open coding conducted over menuscript using three steps; at first step analyze the introductory part of menuscript and the duration to finish undergraduate degree. At the second step, to review technical skills on the process of sofware engineering based on Life Cycle Skill Areas in Software engineering Competency Model (SWECOM) by IEEE Computer Society. At the third step, to identify the complexities of application base on the number of database table dan the number of actor/identity.

Further, selective coding conducted to determine competencies in software engineering. Straus and Corbin (1990) defines selective coding is "the process by which all categories are unified around a "core" category, and categories that need further explication are filled-in with descriptive detail.” (p.14)

\section{Research Object}

Locations of this research are in ten universities under Coordinator for Higher Education (Kopertis) Level Region III. The location of universities that under coordinator of Kopertis III are Jakarta, Tangerang and Bekasi (figure 2). Universities that become object of this research are universities which own the most numerous students in taking Technical Informatics based on database in PPDIKTI 2015. The samples of thesis menuscript are taken from Univercity of Esa unggul, USNI, Bina Nusantara University, Muhammadiyah University, Budiluhur University, STMIK Muhammadiyah, STT PLN, University of Indraprasta PGRI and Univesity of Persada YAI.

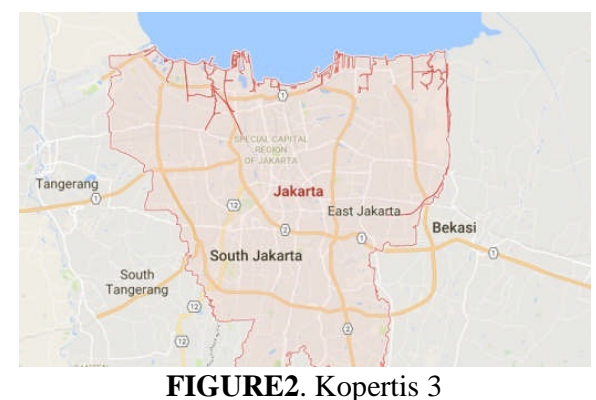

SamplingTechnique

Sampling techniques used in this research is purposive sampling. Data are taken from 10 universities from 54 universities owning study programs of Techical Informatics. The selected universities are the universities which have the most populated students of Technical Informatics based on database of PPDIKTI in 2015. Samples of undergraduate thesis from each universities based on graduation year which is from 2016-2013. Not all university libraries have 2016 undergraduate thesis. Among university libraries which provides 2016 undergraduate thesis are Budi Luhur University, Mercubuana University, Binus University, Muhammadiyah University, university of Esa 
Unggul, USNI and STT PLN. In STT PLN, USNI and Univversity of Esa Unggul, the number of undergraduate thesis are very limited. In universities where 2016 undergraduate thesis have not been available (Table 2) due to administration reason their respective study programs. Many samples taken per year based on the quantity of undergraduate thesis on that year, the more undergraduate thesis in one year the more numerous samples are taken.

TABLE 2. Undergraduate Thesis campus per years

\begin{tabular}{lrrrr}
\hline Campus/Year & 2013 & 2014 & 2015 & 2016 \\
\hline USNI & & 8 & 11 & 1 \\
Binus & & & 11 & 9 \\
Mercu buana & & 4 & 8 & 8 \\
Esa unggul & 5 & 4 & 9 & 2 \\
Muhammadiyah & & 2 & 13 & 5 \\
Budi luhur & & & 1 & 19 \\
STMIK Muh & 14 & & 6 & \\
STT PLN & & 16 & 3 & 1 \\
Unindra & 1 & 12 & 7 & \\
Univ. Pers Yai & & 6 & 14 & \\
\hline & & & &
\end{tabular}

Data Analysis Technique

Menuscipt sample analysis of undergraduate thesis conducted through open coding approach. There are three steps in conducting open coding. Firstly, it analyze titles, abstracts and approval sheets. At this stage, the open coding aims at determing and classifying topics of application based on software domain, software platform and software architecture. At approval sheet is necessary to know the approval dates of the undergraduates thesis. Based on the approval dates can be noticed how long a student spent to complete undergraduate degree. Secondly, open coding results classification of technical skills in process of software engineering based on Life Skill Areas within Software engineering Competency Model (SWECOM) by IEEE Computer Society. Reviewand coding step conducted in every stage of System Development Life Cycle (SDLC).

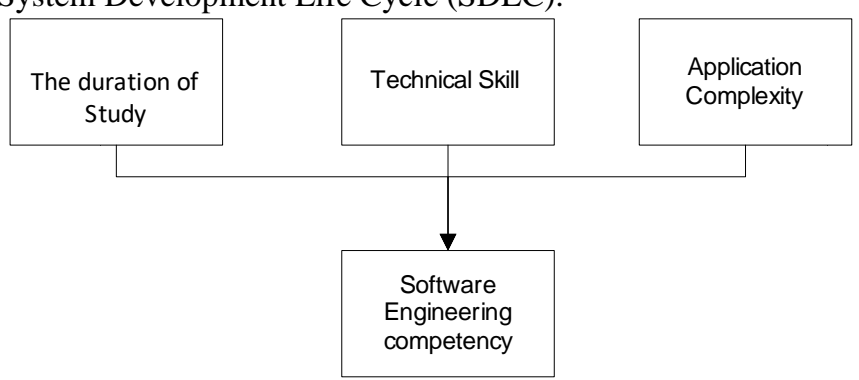

FIGURE 3. Research framework

Thirdly, classificaton the number of tables in database design, the number of actor dealing with application program to see the complexity of application. Further, selective coding is done to determine the competency software engineering of undergraduate students at Coordinator of Private Universities Level Region III. Competencies in software engineering can be known through analyzing the duration of the study, technical skills and complexity of application (figure 3). 


\section{RESULTS AND DISCUSSION}

Well-qualified graduates are the ones who are able to complete their study in Technical Informatics on time. To complete undergraduate degree, a student has to take more or less 7 until 8 semesters. Nearly $50 \%$ of final assignment finished on time, however, many students do not graduate on time which is around 40\% (Figure 4). The remaining graduates which is $10 \%$ finish their study earlier. The graduates who pass earlier are the ones who previously hold diploma degree and continue their study to undergraduate level.

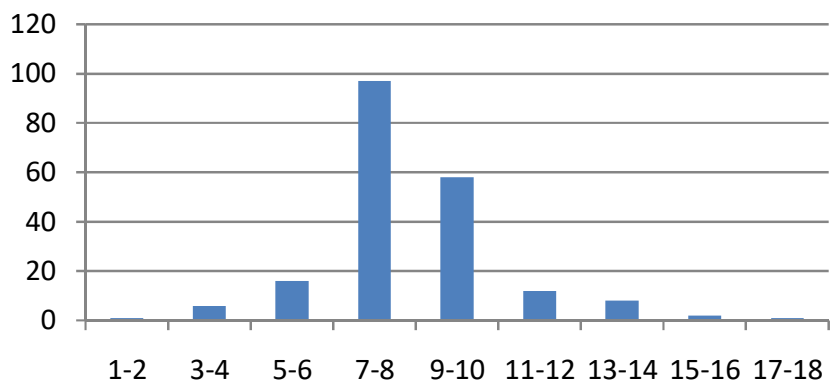

FIGURE 4. Total of Semesters to Complete the Thesis

Application created by graduates of Technical Informatics at Coordinator of Higher Education Region Level III is varied. Application is classified into four domains which are business applications, game applications, educational applications and utility applications and many other apps (Figure 5a). Applications in business is the most numerous application created by graduates of Technical Informatics (69\%). Business application made to support business works. Inventory application, purchasing application, production and management information system are quite many created by students. Students also try to develop game application and all games created run on android based smartphone. Not all universities allow their students to create game application. Game application as research topic is merely found in two universities at Coordinator of Higher Education Region Level III. Other applications that do not include in the classification are related to the field of government and social matter.

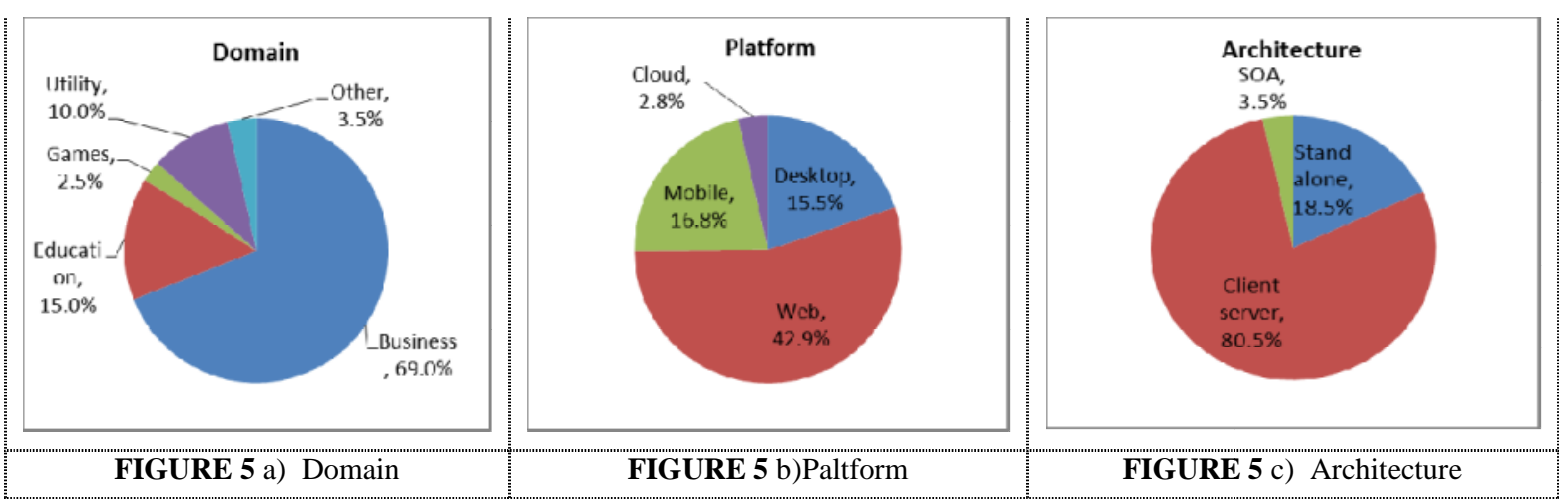

Web platform and mobile platform is the most platform choose by the graduates of Technical Informatics. Some of the applications use two platforms; a web platform as server provides service while clients use mobile platform. Application with mobile platform varies, besides game application, there are some application for utilities and information and this application is usually utilized GPS, like small public minibuses transportation system (angkot) and tourism location system (Figure 5c).

Majority of graduates of Technical Informatics use client-server architecture. Client-server architectureis used to develop web application. While SOA architecture to develop service based application has not gained interest (Figure 5c). 
The discussion above related to general knowledge in the field of software designing that has been done by graduates of Technical Informatics at Kopertis III. Further discussion is on technical skills of graduates based on SWECOM. The discussion begins with analysis step in SDLC.

At the analysis step, one of skills that is required to own by software engineer according to SWECOM is the skill to extract software needs. Skills are related to techniques in engineering requirement. Extraction of application needs for particular purpose is more suitable use interview and observation method while need extraction on applications that will be sold to public is more suitable use questionnaire. In the graduate thesis, a vast majority of students uses interview method and observation, meaning that the product of applications are created to fulfill certain purposes. Few graduates who use questionnaire (Figure 6 a)

Graduate skills in extracting software needs can be known from the transcript of the interview, unfortunately students rarely attach the transcript of the interview at the appendix part of their graduate thesis. Extraction towards software needs is much easier if it is obtained from the right key users. In doing extraction of software needs, many of graduates put the leaders of companies as key users. In fact, students should use head of divisions which is more knowledgeable about the process of their business. Take for an example, for warehouse application, the right key user as source of interview is head of warehouse not director of the company. If students make mistake in choosing the key user, it will be too risky in analyzing and extracting software needs.

The more users get involved in extracting the work needs, the easier to capture business process and the easier to integrate the work needs into the application. In undergraduate thesis of graduates of Technical Informatics at
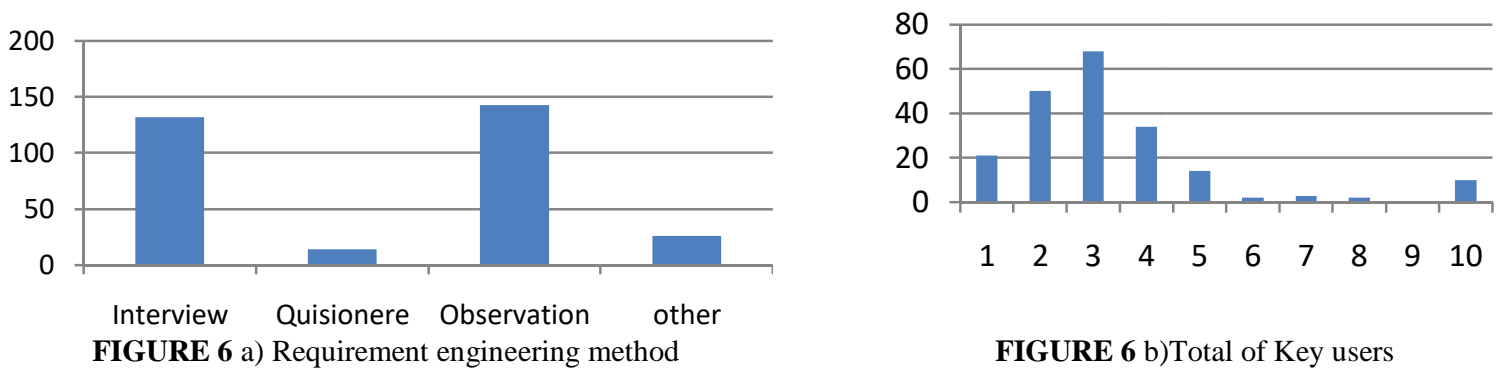

FIGURE 6 a) Requirement engineering method

FIGURE 6 b)Total of Key users

Kopertis III, many of whom interview two or three key users for the applicaton with medium complexities. It would be better if those graduates get involved more key users (figure $6 \mathrm{~b}$ ). The possibility of failure in analyzing and extracting software needs can be occured if key user is not suffient enough.

The next step is to see technical skills in designing software of Technical Informatics graduates. Skills required according to SWECOM are fundamental skills in designing, skills to choose strategies and method in designing software and skills in developing software design architecture. In this research, graduates have used a wide range of modelling (figure 7 a), but many of whom do not use the proper modelling strategies. Modelling with UML can be used for object-oriented software. In contrast, modelling with structured diagram should be used to design processoriented software. (figure $7 \mathrm{~b}$ ). The graduates has been able to develop software design architecture like processs based design; the graduates are able to develop structure diagram start from contextual diagram, zero diagram and detailed diagram. Design architecture of diagrams in UML model can explain the software needs in detail.

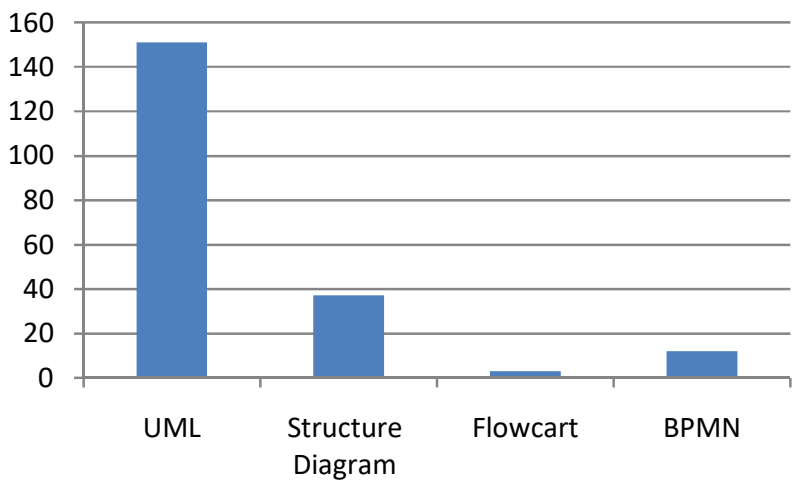

FIGURE 7 a) Modelling Tool

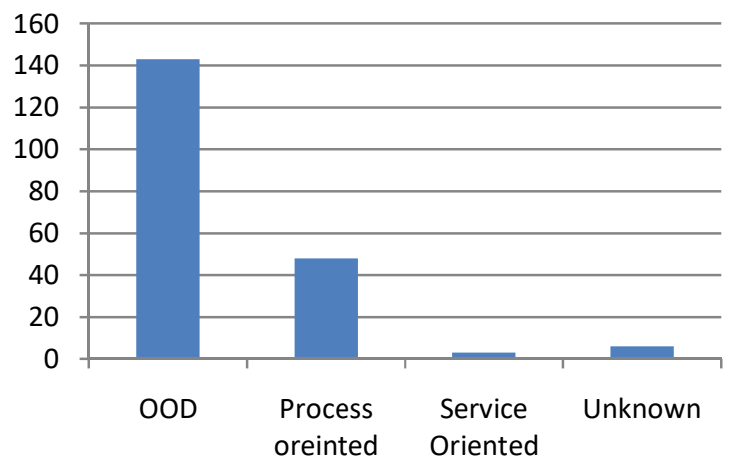

FIGURE 7 b) Design Method 
The next skill is skill in designing software. This skill is related to technical skills in planning of sofware design. The planning includes planning to choose the tool like programming languages ( $8 \mathrm{a}$ ) and planning to choose method used (figure $8 \mathrm{~b}$ ). At planning stage for choosing the tools, graduates are not able to determine the correct tool. Many of the undergraduate thesis explore desktop application design but they use Jave for programming language. Java is made to develop distributed application in order to create application in networking system. Therefore, using Java to develop desktop application is not the right decision.

SWECOM does not explain competencies in regards to using tools because this is more into specific projects. However, to see skills in programming languages, graduates need to know types of programming languages used for application coding. It is broadly known that programming languages used are PHP and Java. The latest programming languages like Phyton has not been used. Most of the graduates use Waterfall method in developing software, while a few graduates that use agile method; there are only two universities use agile method or more precisely is called Scrum method.

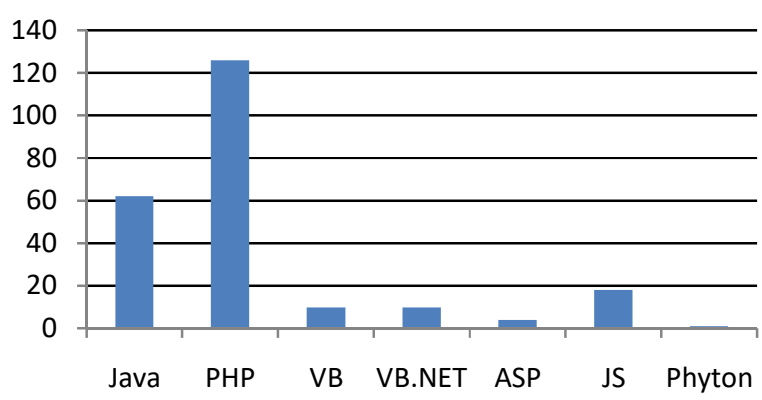

FIGURE 8 a) Program Language

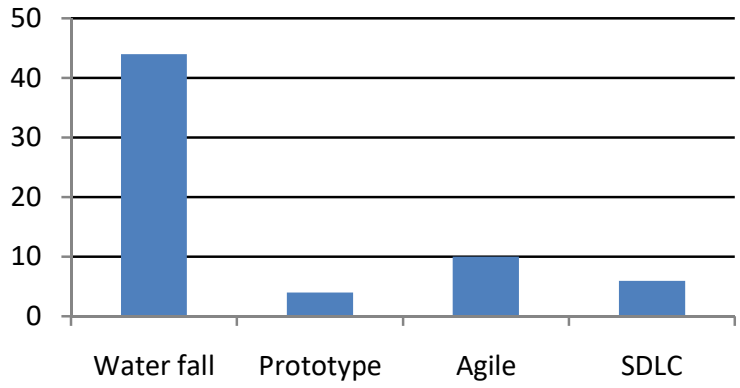

FIGURE 8 b) Development Method

Technical skills required to perform software testing according to SWECOM are skills to design test planning, skillls to organize test infrastructure in form of tool and skill in operating software testing technique. Skills to test application is to assess the display and black box (figure 9). Generallay, graduates merely perform display testing. They capture interface and explain functions related to the interface. Data on skills related to design planning test is not found. Also, data for tool testing is not found in the undergraduate thesis.

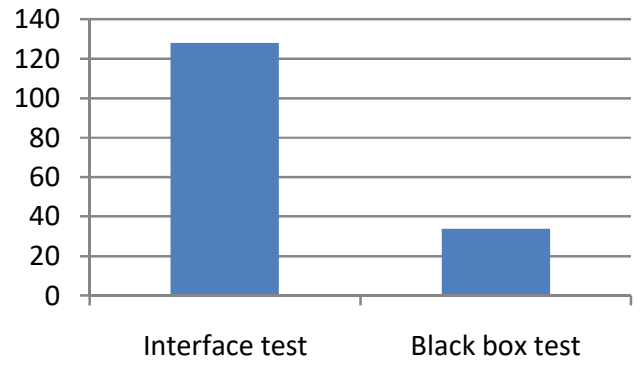

FIGURE 9 Aplication Test Technique

At the third step, open coding technique conducted to see complexities of application developed by graduates of Technical Informatics. Application complexities can be assessed through recognizing some parameters in building program. Some of the parameters are the number of tablesin database design (figure $10 \mathrm{a}$ ), number of actor or entity dealing with designing (figure $10 \mathrm{~b}$ ), Number of tables in database design varies and avaregely the number of tables created by students is 6-7 tables. This research determine that application developed with the number of tables less than 10 is categorized as non complex application, while application with more than 20 tables is categorized as having high complexities. In this research, we do not find many appliaction with tables more than 20. 


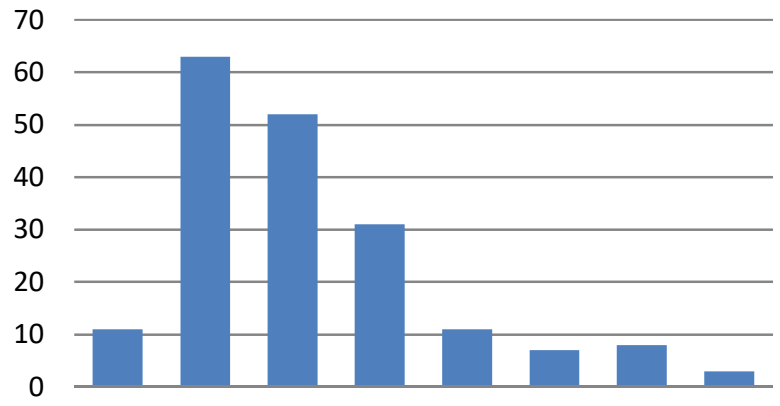

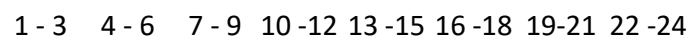

FIGURE 10 a) The Number of Database Table

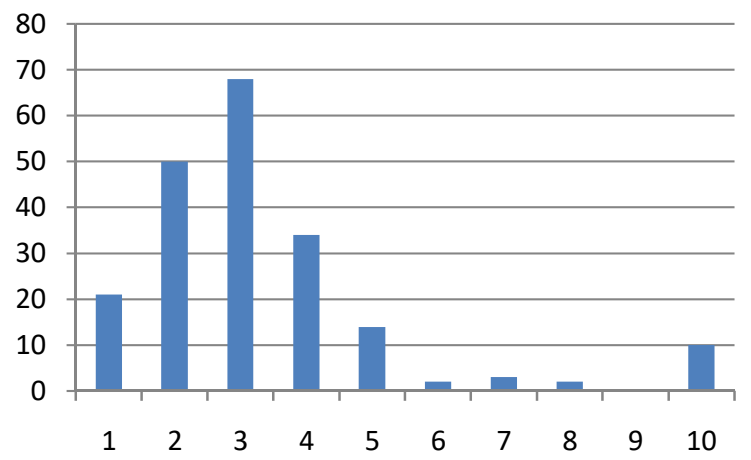

FIGURE 10 b)The Number of Actors/Entity

The more number of stakeholder get involved with the application, the more complex of appliaction. Number of actor or entity in application design found in undergraduate thesis is not too many, 3 actor/entities in avarage. In mobile application, generally the quantity of acto is only two persons, user and administrator. Therefore, the quantity of actor cannot be used to know the complexities of mobile applications.

\section{CONCLUSIONS}

From this research we find that many final assigments with the topic of software engineering conducted undergraduate students of Technical Informatics do not finish their assignment on time, generally speaking they extend the tenure of their course to complete the final assignment. Based on the duration needed to complete the study can be concluded that the graduates are lack of skills in developing application program using tool and metode that they have learnt. Better practicum materials, more excercise and more intensive program can improve programming skills of Technical Informatics students.

Graduates have well-qualified competencies in application design, especially in design method and design architecture, however at level of analysis is necessary to improve their competency in choosing key user to extract sotware needs. At the stage of developing and testing, skills of the graduates need to be improved. In developing of planning of tools used, students should consider to use proper programming languages. Students are in need of knowledge about new method like Scrum to develop application. Through Scrum, students are able to experience working together in a team

There have not been many graduates who create complex application. To develop complex application many human resources are needed while at this one undergraduate thesis done by one student. It is necessary to have new innovation in doing final assignments, let say for example, Binus University that encourages their students to work in a team to finish complex application. Therefore, level of complexities can be improved and of course produces more useful applications.

Mobile applications is one of the software engineering that attract students' interest. And unversities need to response this phenomena through designing teaching curriculum of sofware engineering for mobile applications. In the curriculum of software engineering, it is important to put big effort tp to improve programming techniques of mobile application and to enhance curriculum development in improving application design of mobile application. This kind of development will help government to support the grow of smartphone industry. Government has put software as a part of TKDN (The Level of local content). This new regulation, known as Tingkat Kandungan Dalam Negeri or $(T K D N)$ should be fulfilled if companies want to market their $4 \mathrm{G}$ product in Indonesia. Therefore, to improve TKDN, stakeholders in Smarphone 4G should include local contents in their products. This policy gives tremendous opportunity for those who are dealing with mobile applications. 


\section{REFERENCES}

1. A. Haron, M. Harun, M. N. Mahrim, S. Sahibuddin, N. H. Zakaria, and N. A. Rahman, "Understanding the requirement engineering for Organization:The Challenges", ICMM 8th Intenational Conference, IEEE Explore pp. 561-567, 2012

2. A. M. Yusuf, Asesmen dan Evaluasi Pendidikan, Prenada Media, Jakarta (2015)

3. Bidang KKNI APTIKOM, Naskah Akademik Kerangka Kualifikasi Nasional Indonesia (KKNI) Rumpun Ilmu Informatika dan Komputer, APTIKOM Indonesia, 2014

4. A. Strauss \& J. Corbin, Basics of qualitative research: Grounded theory procedures and techniques. Newbury Park, CA: Sage (1990).

5. B. D. Blansit, Object Oriented Programming: What is IT Talking About?, Journal of Electronic Resources in Medical Libraries, 7:1, 90-97, DOI:10.1080/15424060903585792(2010)

6. B. G.Glaser, and A. L. Strauss, , The Discovery of Grounded Theory: Strategies for Qualitative Research, Aldine, pp 271. (1967)

7. Floyd, C., "A Systematic Look at Prototyping," Approaches to Prototyping (Budde R., Kuhlenkamp K., Mathiassen L., and Zullighoven H., eds.), Springer Verlag, pp. 1-18. (1984)

8. H. Saiedian; D. J. Bagert; N. R. Mead, Software Engineering Programs: Dispelling the Myths and Misconceptions IEEE software (5) (2006)

9. I.M.Wirartha,Pedoman penulisan usulan penelitian, skripsi, dan tesis. Yogyakarta: Andi Offset, (2006)

10. K. M. Eisenhardt, Building Theories from Case Study Research, Academy of Management Review, vol. 14, no. 4, pp 532-550 (1989)

11. M. Apiola dan M.Tedre, New perspectives on the pedagogy of programming in a developing country context, Computer Science Education, Vol. 22(13) (2012)

12. N. Wirth, A Brief History of Software Engineering, IEEE Annalysis of the History of Computing(2006)

13. Okezone.com 9 Prodi Terfavorit di SBMPTN 2014 http://news.okezone.com/read/2014/06/10/373/996894/9prodi-terfavorit-di-sbmptn-2014 (2015)

14. P. Beynon-Davies, Information systems: An introduction to informatics in organisations. Palgrave Macmillan, (2002).

15. P.Ihantola, T. Ahoniemi, V. Karavirta, and O. Seppälä, Review of recent systems for automatic assessment of programming assignments. In Proceedings of the 10th Koli Calling International Conference on Computing Education Research (pp. 86-93). ACM.

16. P.E Widoyoko, Evaluasi Program pembelajaran, Pustaka Pelajar Yogyakarta(2009)

S. Gross, dan N. Pinkwart, Towards an Integrative Learning Environment for Java Programming. IEEE 15th International Conference on Advanced Learning Technologies 25-28(2015) 